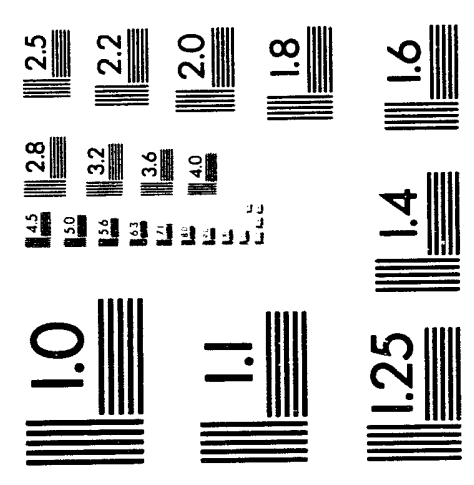



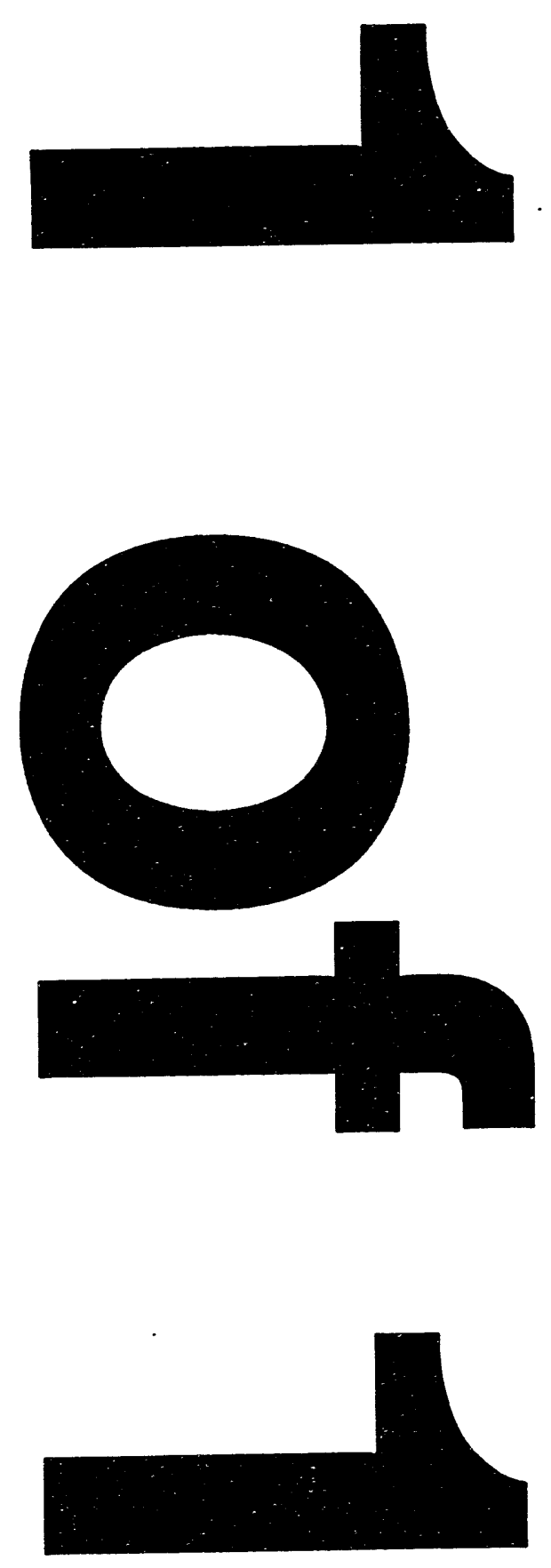
DOE/RL-94-37

UC-630

\title{
The Hanford Site Focus, 1994
}

\author{
J. M. Peterson \\ Date Published \\ March 1994
}

Prepared for the U.S. Department of Energy

Office of Environmental Restoration and

Waste Management

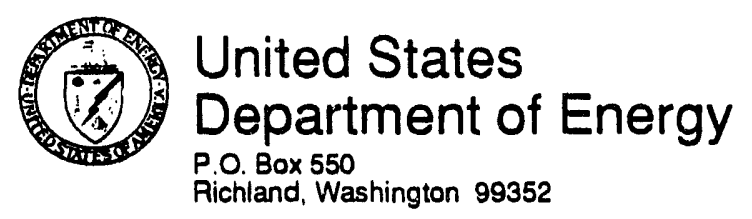

Approved for Public Release 
DOE/RL-94-37

This page intentionally left blank. 


\section{TABLE OF CONTENTS}

I. GENERAL OVERVIEW OF THE HANFORD MISSION $\ldots \ldots \ldots \ldots \ldots \ldots 1$ Introduction $\ldots \ldots \ldots \ldots \ldots \ldots \ldots \ldots \ldots \ldots \ldots \ldots$ Hanford Site Vision $\ldots \ldots \ldots \ldots \ldots \ldots \ldots \ldots \ldots \ldots$

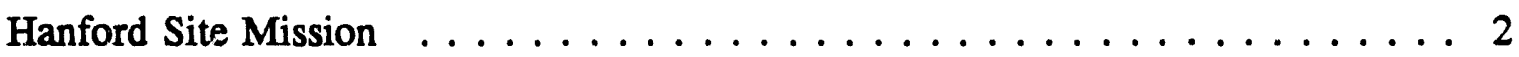

Hanford Site Goals . . . . . . . . . . . . . . . . . 2

II. HANFORD SITE PRIORITIES $\ldots \ldots \ldots \ldots \ldots \ldots \ldots \ldots$

III. THE FRAMEWORK FOR HANFORD SITE CLEANUP $\ldots \ldots \ldots \ldots \ldots 7$

The Tri-Party Agreement . . . . . . . . . . . . . . . . 7

Environmental Restoration and Waste Management $\ldots \ldots \ldots \ldots \ldots \ldots$

FY 1993 Accomplishments . . . . . . . . . . . . . . . . . . 10

FY 1994 Environmental Management Program Budget Summary . . . . . . . 12

IV. PROGRAM AREA SUMMARY $\ldots \ldots \ldots \ldots \ldots \ldots \ldots \ldots$

TANK WASTE REMEDIATION SYSTEM $\ldots \ldots \ldots \ldots \ldots \ldots \ldots \ldots$

SOLID WASTE $\ldots \ldots \ldots \ldots \ldots \ldots \ldots \ldots \ldots \ldots \ldots$

LIQUID EFFLUENTS $\ldots \ldots \ldots \ldots \ldots \ldots \ldots \ldots \ldots \ldots$

WASTE AND DECONTAMINATION SERVICES $\ldots \ldots \ldots \ldots \ldots 21$

FACILITIES OPERATIONS $\ldots \ldots \ldots \ldots \ldots \ldots \ldots \ldots \ldots$

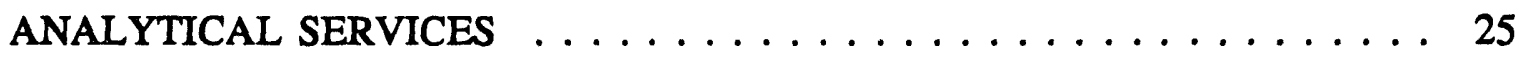

OTHER WASTE MANAGEMENT $\ldots \ldots \ldots \ldots \ldots \ldots \ldots \ldots 27$

RCRA \& Operational Monitoring Programs . . . . . . . . . . 27

Planning Integration Program $\ldots \ldots \ldots \ldots \ldots \ldots \ldots . \ldots \ldots$

Hanford Environmental Management Program . . . . . . . . . . 27

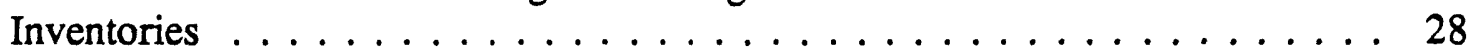

DOE-Richland Directed Activities $\ldots \ldots \ldots \ldots \ldots \ldots \ldots \ldots \ldots$

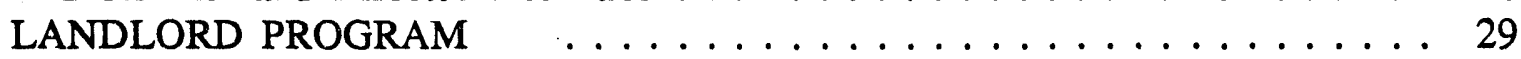

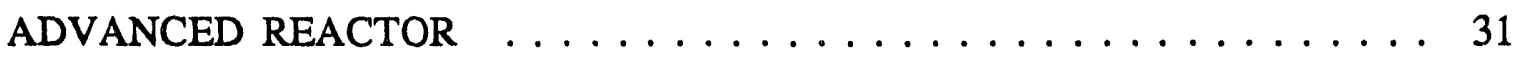

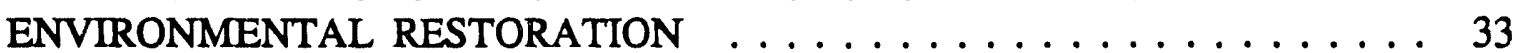

TECHNOLOGY DEVELOPMENT NATIONAL PROGRAM $\ldots \ldots \ldots \ldots 37$

SCIENCE AND TECHNOLOGY RESEARCH SUPPORT $\ldots \ldots \ldots \ldots \ldots 39$

V. INTERNATIONAL ENVIRONMENTAL INSTITUTE $\ldots \ldots \ldots \ldots \ldots . \ldots 40$

VI. EMPLOYMENT PROJECTIONS FOR THE HANFORD SITE . . . . . . . . 43

VII. FY 1995 CONGRESSIONAL BUDGET REQUEST $\ldots \ldots \ldots \ldots \ldots \ldots$. . . 45

VIII. LIST OF TERMS $\ldots \ldots \ldots \ldots \ldots \ldots \ldots \ldots \ldots \ldots \ldots$

IX. $\quad$ GLOSSARY . . . . . . . . . . . . . . . . . 49

X. TRI-PARTY AGREEMENT MAJOR MILESTONES $\ldots \ldots \ldots \ldots \ldots \ldots$ 
This page intentionally left blank. 


\section{GENERAL OVERVIEW OF THE HANFORD SITE MISSION}

\section{Introduction}

Understanding the Hanford Site has been described as similar to dancing with an octopus. So is describing Hanford Site problems and plans.

This report describes what the Hanford Site will look like in the next two years. We offer thumbnail sketches of Hanford Site programs and the needs we are meeting through our efforts. We describe our goals, some recent accomplishments, the work we will do in fiscal year (FY) 1994, the major activities the FY 1995 budget request covers, and the economic picture in the next few years.

The Hanford Site budget shows the type of work being planned. U. S. Department of Energy (DOE) sites like the Hanford Site use documents called Activity Data Sheets to meet this need. These are building blocks that are included in the budget.

Each Activity Data Sheet is a concise (usually 4 or 5 pages) summary of a piece of work funded by the DOE's Environmental Restoration and Waste Management budget. Each sheet describes a waste management or environmental restoration need over a 5-year period; related regulatory requirements and agreements; and the cost, milestones, and steps proposed to meet the need.

The Hanford Site is complex and has a huge budget, and its Activity Data Sheets run to literally thousands of pages. This report summarizes the Activity Data Sheets in a less detailed and much more reader-friendly fashion. We hope this report helps you understand how we are spending tax dollars at the Hanford Site.

\section{Hanford Site Vision}

Our vision at the Hanford Site is a shared vision. The DOE, its contractors, regulators, technical experts, and the public work together to accomplish this vision. We are building a clean, accessible, and healthy environment that is part of a prospering and diversified community. We are reaching beyond our past achievements to continue a tradition of excellence in scientific and technological accomplishments. We are a resource nations can turn to for solutions to environmental challenges. 


\section{Hanford Site Mission}

The primary mission is to clean up the radioactive and hazardous wastes at the Hanford Site, to provide scientific and technological excellence to meet global needs, and to work with other groups in the economic diversification of the region. Achieving excellence of operations in all of the mission area activities enables us to achieve our goal.

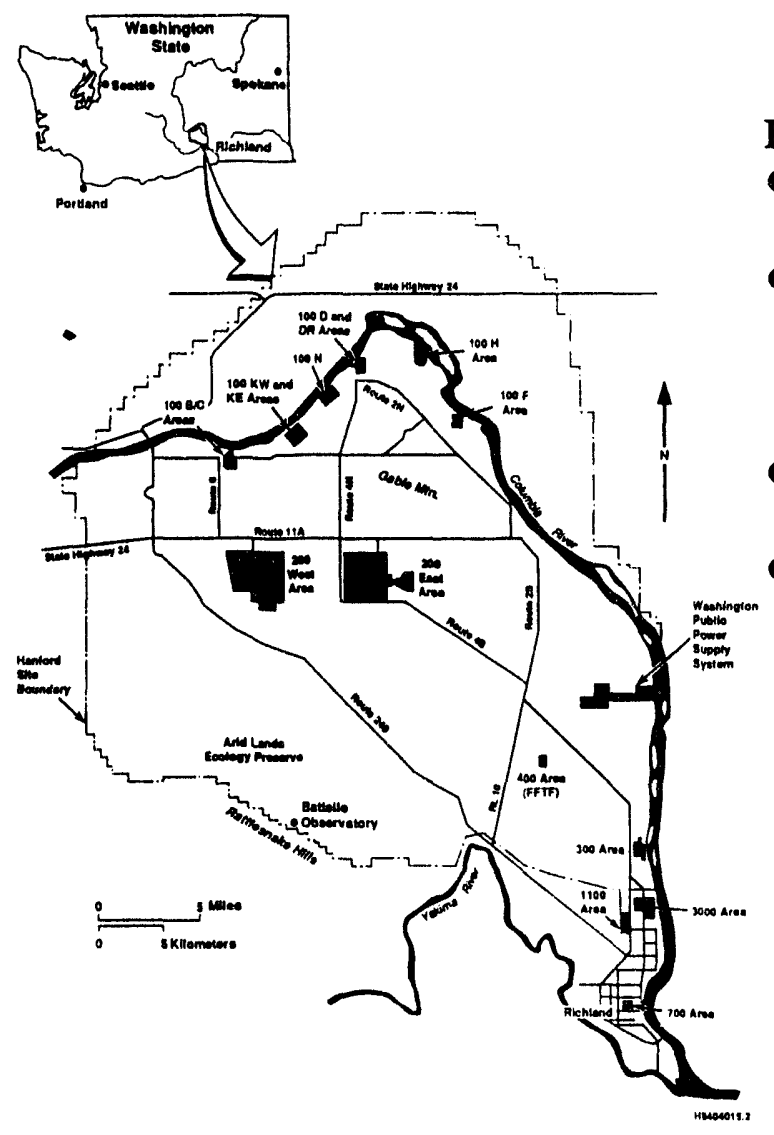

Key Notes

- The Hanford Site is a key part of the single largest environmental program in the world.

- Nearly 50 years of nuclear weapons production has resulted in $1,344,000$ metric tons of solid and liquid wastes stored or disposed of at the Hanford Site.

- More than 1,500 contaminated sites are slated for cleanup at the Hanford Site.

- DOE allocates $34 \%$ of its total resources to the national cleanup program.

- The Hanford Site FY 1994 budget for environmental cleanup is $\$ 1.524$ million.

\section{Hanford Site Goals}

The Assistant Secretary for Environmental Restoration and Waste Management (ER/WM, also known as Environmental Management--EM), has established six essential program goals for FY 1994. These goals are:

- Eliminate and manage the urgent risks and inherent threats in our system.

- Provide a safe workplace that is free from accidents, injuries, and adverse health effects.

- Establish a system that is in control managerially and financially. 


\section{DOE/RL-94-37}

- Demonstrate tangible, outcome-oriented results.

- Identify and overcome obstacles to success in the Technology Development Program to ensure that these efforts will benefit the civilian economy.

- Develop a stronger partnership between DOE and its stakeholders.

At the Hanford Site, we are committed to reach each goal. Additionally, we have defined the following site-specific goals and key factors to operational excellence to help us reach our vision for the Hanford Site.

- We will reduce risks to the public, workers, and environment.

- We will comply with appropriate safety and environmental regulations and our stakeholders accept our performance with compliance.

- We will clean up the materials, facilities, and wastes (including cleanup byproducts and infrastructure) left after nearly 50 years of nuclear weapons work consistent with land use plans and applicable regulations. This includes the following actions:

- $\quad$ Safely store and dispose nuclear fuels on a long-term basis.

- Treat and dispose tank farm low-activity and high-activity waste.

- Treat and dispose contaminated and radioactive solid waste.

- $\quad$ Stop discharging untreated liquid wastes to the soil.

- Clean up sites where solid wastes were buried or liquid wastes were discharged to the ground in the past, but no longer.

- Safely shut down production facilities and decontaminate and decommission the facilities.

- We will transfer land and other resources for other socially beneficial uses.

- We will ensure the resources we develop and use for cleanup (e.g., technology, people, expertise) enhance the economic vitality of the region.

- We will seek recognition for our leadership in cleanup science and technology. 
DOE/RL-94-37

This page intentionally left blank. 


\section{HANFORD SITE PRIORITIES}

We have a priority system to help allocate funds and plan work scope to meet the cleanup mission. We've defined thase priorities in further detail to apply to the Environmental Restoration and Waste Management programs on the Hanford Site. Here is our expanded priority system:

- Safe cleanup operations. Work to resolve open and imminent safety issues through characterization, analysis, mitigation, and remediation efforts.

Maintain facilities safely.

- Develop or revise safety analysis reports.

- Operate and maintain safety-related equipment and systems such as alarms, ventilation, electrical, and fire protection. The work includes repairs and upgrades for equipment needed to keep facilities safe.

- Maintain key infrastructure facilities that directly relate to safe facility configurations (i.e., steam and laboratory support).

- Maintain adequate tank capacity and support operation.

- $\quad$ Reduce exposure and risks in the Plutonium Finishing Plant (PFP) in parallel with National Environmental Policy Act (NEPA) process.

- Compliance. Comply with environmental laws and the Hanford Federal Facility Agreement and Consent Order (Tri-Party Agreement). Meet milestones on schedule. Also include the following activities:

- $\quad$ Administer the Tri-Party Agreement

- Interpret regulations

- Monitor and report.

Pursue corrective actions that deal with the following compliance issues:

- Facility upgrades (for example, stop effluent flow or treat the effluents)

- Stay in compliance (for example, adhere to 90-day storage provisions of hazardous waste laws). 


\section{DOE/RL-94-37}

- Safety Assurance. Enhance public safety by--

- Monitoring air and water for radioactive and hazardous emissions

- $\quad$ Providing emergency preparedness capability to respond to events.

Enhance worker safety by--

- Occupational Safety and Health Administration compliance

- Radiation protection

- Fire protection

- Industrial hygiene

- Programs to allow employees to express concerns (anonymously if desired) without fear of repercussions.

- Compliance Assurance. Ensure adherence to DOE Orders related to environment and safety by--

- Interpreting and assessing the orders

- Taking corrective actions needed to comply with DOE Orders.

- Conduct of Operations. Pursue effective conduct of operations by--

- Developing procedures

- Training

- $\quad$ Conducting Operational Readiness Reviews

- $\quad$ Reporting occurrence

- $\quad$ Completing milestones on time.

- Enhanced Operations. Pursue activities that are not required by regulations but are desirable, such as:

- Comply with DOE Orders more stringent than external regulations

- Improve management practices

- Meet milestones ahead of schedule

- Improve cost effectiveness of efficiency of operations. 


\section{THE FRAMEWORK FOR HANFORD SITE CLEANUP}

\section{The Tri-Party Agreement}

In the mid-1980s came an increased public awareness of the need to clean up the waste that had accumulated over the past 49 years. Part of the problem facing DOE, the Washington State Department of Ecology (Ecology), and the U.S. Environmental Protection Agency (EPA) was applying environmental regulations not designed for facilities like those at the Hanford Site. The solution: a legally binding agreement called the Hanford Federal Facility Agreement and Consent Order, or Tri-Party Agreement, containing specific cleanup milestones. Signed in 1989, the Tri-Party Agreement was the first of its kind and has led to similar agreements at other DOE facilities.

In essence, the Tri-Party Agreement sets out an orderly way to apply environmental regulations at more than 50 treatment, storage, and disposal facilities and more than 1,100 inactive Hanford waste sites. The Tri-Party Agreement's goal was to establish realistic timetables leading to the cleanup of the Hanford Site. As of the end of January 1994, we completed 293 of 294 milestones on or ahead of schedule. We list all the major Tri-Party Agreement milestones in section X.

In September 1993, the three parties ended several months of negotiations that resulted in major changes to the agreement. The following summarizes those changes approved on January 25, 1994.

- Cease further development of grout, a process to mix low-activity waste with cement-like material for near-surface burial.

- Start construction on a facility to pretreat waste to separate low-activity waste from high-activity waste in preparation for final processing.

- Delay the start of construction on a high-activity waste vitrification plant (HWVP) until 2005.

- Begin a pilot-scale project to pump and treat contaminated groundwater.

- Work with EPA and Ecology to set priorities and funding levels for the activities in the Environmental Management program.

- Include the decontamination and decommissioning of major facilities like $\mathrm{N}$ Reactor and the Plutonium-Uranium Extraction (PUREX) facility in the Tri-Party Agreement. 
The Hanford Advisory Board, made up of 32 stakeholder representatives, was convened in January, 1994. The Hanford Advisory Board will provide DOE, Ecology, and EPA with advice on major policy issues. We see this as forging an improved relationship with our stakeholders.

\section{Environmental Restoration and Waste Management}

The DOE reorganized and created the office of Environmental Management in 1990 to raise the visibility of DOE's environmental cleanup efforts. The cleanup activities managed by EM at the Hanford Site use about $81 \%$ of the total Hanford Site budget for FY 1994. 
Following is the Work Breakdown Structure for the major EM programs to meet the Hanford Site mission.

\section{Work Breakdown Structure}

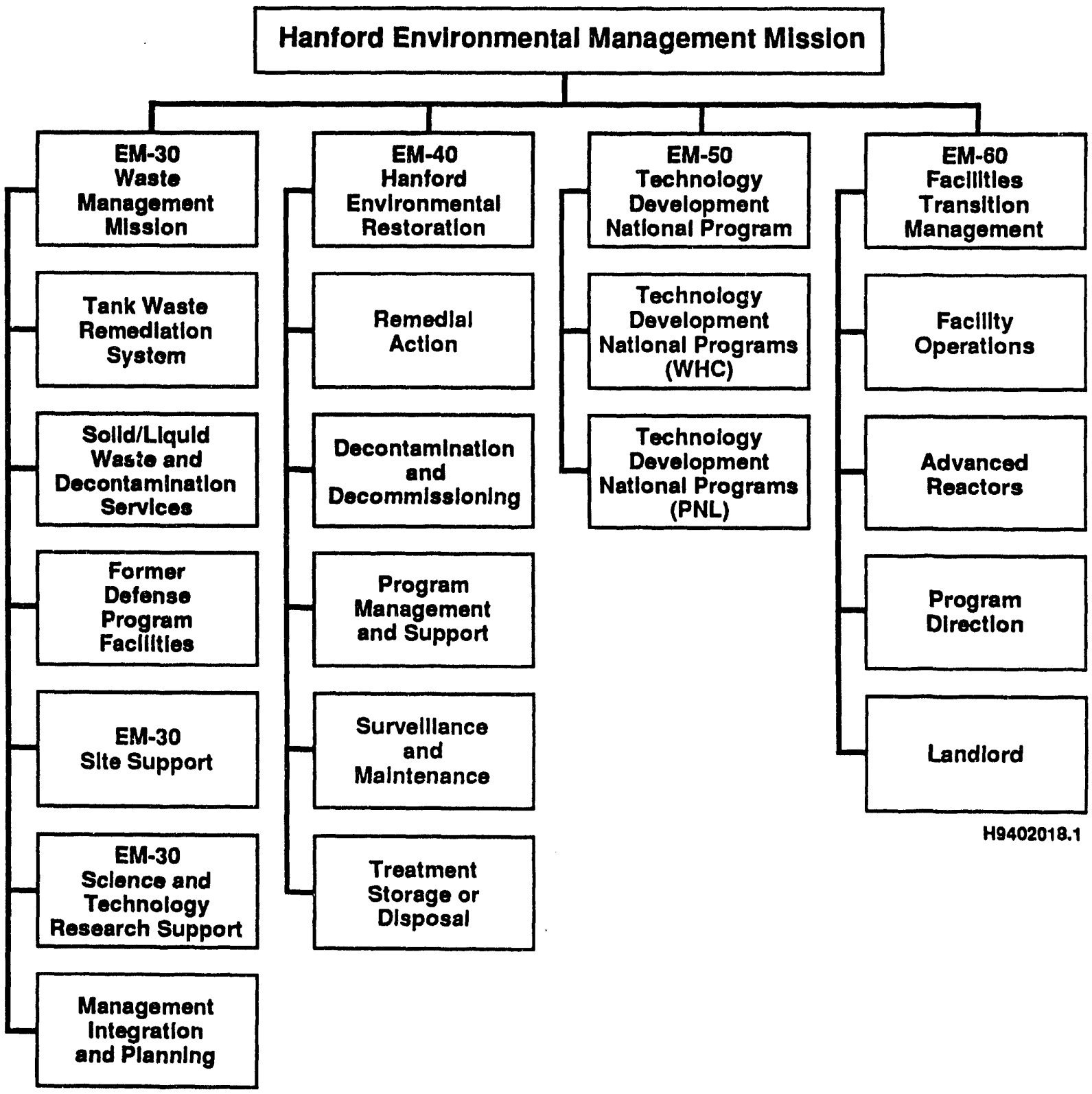




\section{FY 1993 Accomplishments}

Working toward the Hanford Site ultimate cleanup goal, we have had many achievements in the past year. While it would be impossible to acknowledge every item, we've listed contains some of our accomplishments in FY 1993.

\section{Safety}

- We speeded up new initiatives to strengthen conduct of operations and management training. We enhanced operator training and certification and implementation of job hazard analysis. We developed and put in place an upgraded training and qualification program for nuclear process operators. We also have more hands-on training for health physics technicians emphasizing safety lessons learned in the workplace.

- The Mobile Surface Contamination Monitor II is up and running and has characterized surface contamination over a 60-acre area near $\mathrm{N}$ Reactor.

- We established a Hanford Safety Team.

- We demolished an unneeded and potentially hazardous facility--the 190B Building.

\section{Reinventing Government}

- Energy Secretary O'Leary selected Hanford as one of six DOE sites for designation as a reinventing government laboratory. The success of our realignment of our security forces and programs and the privatization of the laundry prompted this selection.

\section{Operations}

- We completed the $\mathrm{UO}_{3}$ Plant's final campaign, which converted a corrosive and unstable liquid mixture, uranyl nitrate hexahydrate, into a solid and stable powder form, $\mathrm{UO}_{3}$.

- We removed sludge to allow installation of encapsulation equipment in the $\mathrm{K}$ East Basin discharge chute.

- We significantly reduced the time for waste tank analysis at the 222-S and 325 laboratories.

- We completed a major step in the planning to safely transition the PUREX facility We also made good progress on the cleanout of B Plant.

- Tank Waste Remediation System (TWRS) completed several milestones. We: 


\section{DOE/RL-94-37}

- $\quad$ pumped 23,300 gallons of waste from Tank 241-T-101

- $\quad$ installed mitigation mixer pump in Tank 241-SY-101

- $\quad$ retrieved seven core samples from three single-shell tanks and five grab samples from five double-shell tanks

- issued an integrated retrieval program plan for DOE-Headquarters

- submitted selection criteria, retrieval approach, and recommendation of Tank 106-C as first single-shell tank to be retrieved

- issued a plan for pretreatment technology

- $\quad$ finished a study on waste pretreatment feed optimization

\section{General}

- Began preliminary design for the next tank farm to be built here.

- Westinghouse Hanford Company (WHC) incorporated \$1.8 million of improved methods for conducting our mission through a program to share ideas with Westinghouse contractors at other DOE sites. WHC employees also found ways to avoid $\$ 126.3$ million in costs.

- We turned over the site laundry services to Interstate Nuclear Services on schedule in August. We worked closely with displaced laundry workers to help them with career counseling, skills identification, job interest evaluations, and some new skills training. Their placement in new positions or in retraining is progressing well.

- WHC is a partner in the newly formed Tri-City Commercialization Partnership. The partnership won a $\$ 150,000$ grant for the National Technology Transfer Center to establish a Regional Technology Transfer Center in the Tri-Cities.

- We renegotiated the Tri-Party Agreement.

- We successfully completed the first-ever Hanford Summit. 


\section{FY 1994 Environmental Management Program Budget Summary}

The major segments of the Hanford EM program are TWRS, Solid and Liquid Waste, other Waste Management programs, Facilities Transition, Environmental Restoration, and Technology Development.

The TWRS program makes up the single largest component of the Hanford EM program. TWRS is focused on treating, storing and disposing of wastes from single- and double-shell tanks in a safe, cost-effective and environmentally sound manner. TWRS operations include rehabilitating the waste tank infrastructure and reducing the potential for future leaks.

The Solid and Liquid Waste segment is actually composed of three separate programs: Solid Waste, Liquid Effluents, and Waste and Decontamination Services. Collectively, these programs manage solid and liquid wastes, including repackaging, and provide decontamination services.

The other Waste Management programs include a variety of efforts. They include portions of Facility Operations that relate to the K Basins and to B Plant and the Waste Encapsulation and Storage Facility. Analytical Services covers laboratory services like field sampling, field screening, and data collection. The RCRA and Operational Monicoring program monitors the environment immediately next to site facilities to discern the effects of site activities. Planning Integration handles integrated site planning. The Hanford Environmental Management Program provides general support that ensures compliance with environmental requirements across the site. Another program, Inventories, manages the site's inventories. Also grouped with the Waste Management programs are DOE-Richlanddirected activities like oversight functions performed by federal employees, grants to nearby tribal governments, and the coordination with the regulators and stakeholders on Tri-Party Agreement activities.

The Facilities Transition segment has the activities in the major part of the Facilities Operations Program (i.e., PUREX and PFP), the Landlord Program, the Advanced Reactor Program (mainly dealing with the Fast Flux Test Facility (FFTF), and the DOE-Richland directed activities that support these programs. Facilities Transition programs deal with everything from replacing, repairing and upgrading the existing Hanford Site infrastructure to providing safe, secure, and environmentally sound management of former defense nuclear and energy research facilities.

The Environmental Restoration Program was established to plan, carry out, and control the remediation efforts on site. This includes cleanup of inactive Hanford waste sites, the surveillance and maintenance of facilities that are no longer needed, and decontamination and decommissioning of facilities. 


\section{DOE/RL-94-37}

The final component of the Hanford EM program is Technology Development. This program develops better ways to measure, analyze, and dispose of waste. It is managed at Headquarters and is very important to the continued efforts to make DOE's site cleanup more cost-effective.

The following chart illustrates how the FY 1994 funding is allocated among the major segments of the Hanford Site EM program.

\section{Total Environmental Management Program \$1524 (\$ in Millions)}

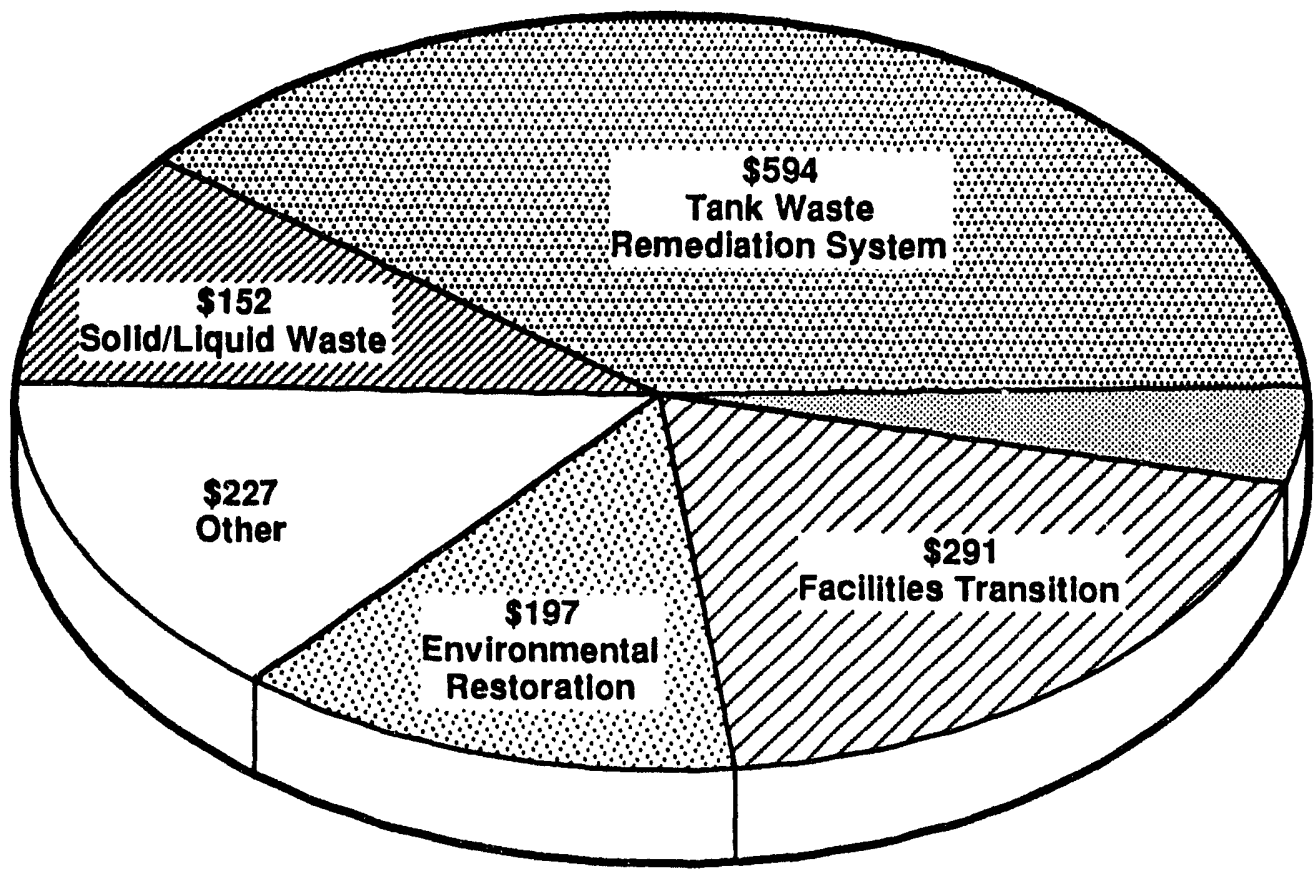


This page intentionally left blank. 


\section{PROGRAM AREA SUMMARY}

Below we explain how we have divided the Hanford Site cleanup mission into the major programs. We describe the programs' missions and the major work (objectives) they have planned. We also show the major milestones due in the next year and the budget earmarked for these efforts.

\section{TANK WASTE REMEDIATION SYSTEM}

Mission

The TWRS program mission is treat, store, and dispose of waste in a safe, costeffective, and environmentally sound manner. These wastes include current and future tank waste, and capsules that store highly radioactive cesium and strontium.

We will carry out the TWRS mission by studying the wastes, resolving safety issues, upgrading the waste tank infrastructure, keeping the waste tank and capsule storage facilities operating safely, and reducing the potential for future leaks.

The mission also involves developing, building, and operating retrieval equipment and facilities for pretreatment (waste separation), waste treatment and disposal, and interim storage of glass canisters, cesium and strontium capsules, and other nuclear material. We will pursue commercial and DOE technologies aggressively, and develop alternative technologies to support this mission.

\section{Objectives}

- Identify and resolve tank safety issues as first priority so that no preventable event can occur to expose workers or the public to unsafe levels of radiation or hazardous chemicals.

- Establish a safe and environmentally sound basis for tank farms; upgrade as necessary, and operate and maintain accordingly.

- Characterize the waste to provide the data necessary to store the waste safely and to enable waste retrieval, processing, and disposal.

- Separate the waste into low-activity and high-activity waste and transuranic waste so that the bulk of chemicals are in the low-activity waste, and the bulk of radionuclides are in the high-activity waste.

- Remove radionuclides from the low-activity waste stream to meet the U.S. Nuclear Regulatory Commissions's "incidental waste" classification, and the DOE's "as low as reasonably achievable" (ALARA) policy. 


\section{DOE/RL-94-37}

- Retrieve the single-shell tank waste by 2018 , and immobilize all waste by 2028.

- Reduce the volume of high-activity waste so that the immobilized volume is acceptable to the national program for deep geologic disposal of nuclear wastes.

- Vitrify the low-activity waste and dispose of it onsite and near the surface in a retrievable form.

- Vitrify the high-activity waste and place it in containers that meet standards for the national program for deep geologic disposal of nuclear wastes; store the waste containers until they can be shipped to a geologic repository.

- Safely store the strontium and cesium capsules until they can be packaged and shipped to a geologic repository for disposal; package the capsules as needed to meet the geologic repository program requirements.

\section{Major Milestones}

- Close the Ferrocyanide, Tank 241-C-103 Vapor, and Criticality Unreviewed Safety Questions.

- Complete installation of gas monitoring equipment in the potentially flammable double shell tanks.

- Initiate interim stabilization of five single shell tanks.

- Continue major maintenance and restoration of Tank Farms Facilities and technical documentation.

- Begin low-activity waste melter testing and simulants.

- Initiate construction of 200 West Area double shell tanks.

- Place Grout Treatment Facility in cold standby.

\section{Cost Baseline Summary}

The FY 1994 budget for TWRS is $\$ 594$ million, which is about a $18 \%$ increase from the FY 1993 funding level. 
Mission

The Solid Waste Program provides a comprehensive approach for the storage, treatment, and disposal of current and future solid waste at the Hanford Site (from onsite and offsite generators). The approach is compliant with regulations, orders, permits, and safety analyses. The program includes activities needed to dispose of selected wastes now in retrievable storage. It provides a central focus for control of cost, scope, and schedule of Hanford Site solid waste activities and communications about those activities.

The SWP pursues excellence in environmental management through Value Engineering, Total Quality initiatives, sharing cost and efficiency ideas with Westinghouse contractors at other DOE sites, and demonstrating and applying advanced technologies. The long-term goal of the Solid Waste Program is to eliminate the indefinite storage of transuranic and mixed waste, and dispose of all solid waste under this program in a safe, environmentally compliant, and cost-effective manner.

\section{Objectives}

- Start construction of the Waste Receiving and Processing-Module I facility (WRAP I).

- Support the start of operation of the WRAP I through planning.

- Continue characterization and documentation of current and future solid waste inventories.

- Establish criteria for new facilities' development.

- Maintain permits that comply with state and federal requirements.

- Publish solid waste characterization and treatment strategy plans.

- Establish and maintain safety criteria and procedures for the operation of solid waste facilities.

- Maintain solid waste facilities in an environmentally sound and compliant manner.

- Develop and apply new technology for solid waste handling, characterization, treatment, storage, and disposal.

- Start solid waste reduction services.

- Perform W-025, "Radioactive Mixed Waste Disposal Facility," readiness review and commence operations. 


\section{DOE/RL-94-37}

\section{Major Milestones}

- Initiate detail design of SWOC.

- Initiate Waste Receiving and Packaging Plant (WRAP) I Construction.

- Backlog waste completion.

- Mixed waste construction completed.

- Issue RFP for thermal and sodium treatment, low-activity volum reduction.

- Initiate pilot transuranic retrieval.

- $183 \mathrm{H}$ testing complete.

\section{Cost Baseline Summary}

The FY 1994 budget for solid waste is $\$ 81$ million, which is about a $34 \%$ increase from the FY 1993 funding level. 


\section{LIQUID EFFLUENTS}

\section{Mission}

The Liquid Effluents Program mission is to eliminate the use of soil for liquid effluent treatment and manage current and future liquid effluent streams in a safe, responsible, cost-effective, and legally compliant manner. This is achieved through planning and integration, public and stakeholder interaction, definition of requirements for generators and provision of timely treatment, storage, disposal capacity, and waste minimization of waste streams where applicable.

\section{Objectives}

- Complete building the 200 Areas Effluent Treatment Facility and begin testing in preparation for startup in June 1995 for the processing of 242-A Evaporator condensate.

- Complete the construction of the 200 Areas Treated Effluent Disposal Facility to collect certain 200 Areas effluent streams after using best available technology and begin discharge to a State-permitted disposal facility for those effluents by June 1995.

- Implement best available technology or all known, available and reasonable methods of prevention, control and treatment for Phase II liquid effluent streams by October 1997.

- Complete the construction of the 300 Area Treated Effluent Disposal Facility and begin testing to prepare for startup in December 1994 to treat and dispose of the 300 Area process sewer wastewaters.

- Pursue full regulatory compliance of all liquid effluent streams that are not included within the original 33 Phase I and Phase II streams. These streams are referred to as miscellaneous streams. We will complete a plan and schedule for regulatory compliance in FY 1994.

- Through a systems engineering approach, we will help develop long-range plans, do engineering evaluations, investigate new feeds to treatment plants, and integrate future liquid effluent projects into existing liquid effluents treatment facilities and infrastructures. 


\section{Major Milestones}

- Complete construction of the (L-045H) 300 Area Treated Effluent Disposal Facility (TEDF).

- Completed construction of the (C-018H) 200 Area Effluent Treatment Facility (ETF).

- Completed construction of the (W-049H) 200 Area TEDF collection and disposal systems.

\section{Cost Baseline Summary}

The FY 1994 budget for Liquid Effluents is $\$ 46$ million, which is about a 37\% decrease from the FY 1993 funding level. The decrease is primarily because we finished several construction projects associated with the Hanford Environmental Compliance project. The FY 1994 operating expense budget for liquid effluents has increased $60 \%$ from FY 1993. 


\section{WASTE AND DECONTAMINATION SERVICES}

\section{Mission}

The mission of the Waste and Decontamination Services program is to provide decontamination services, waste treatment, and waste repackaging services; procure, certify, repair and decontaminate liquid waste tank cars; and store and keep surveillance for the Pressurized Waste Reactor Core II irradiated fuel elements until final disposition.

\section{Objectives}

- Ensure safety through continued operational and radiological surveillances of all systems and grounds, and store 72 irradiated Pressurized Waste Reactor Core fuel elements. Maintain the existing pool and related equipment. Continue to support the planning to remove and finally deal with irradiated fuels.

- Operate and maintain treatment, storage, and disposal facilities for the management of radioactive and hazardous wastes on the Hanford Site.

- Provide a liquid waste transfer system (tanker car), as a backup to the piping system, for the transfer of liquid wastes.

- Keep on schedule for work the Tri-Party Agreement and Ecology compliance schedules cover.

\section{Major Milestones}

- Restart 2706-T low-activity decontamination facility.

- Disposition of high dose level DRAG OFF Box in T-Plant Canyon.

- Complete backup log container repackaging.

- Modify 2706-T tagging pad to eliminate accumulation of precipitation.

\section{Cost Baseline Summary}

The FY 1994 budget for Waste and Decontamination Services is $\$ 25$ million. This is about a 15\% decrease from the FY 1993 funding level. 
DOE/RL-94-37

This page intentionally left blank. 


\section{FACILITIES OPERATIONS}

\section{Mission}

The Facility Operations Program provides safe, secure, and environmentally sound management of the former defense nuclear production facilities and the disposition of the nuclear materials associated with these facilities. The Facility Operations Program consists of the PFP, PUREX and $\mathrm{UO}_{3}$ Plant, B Plant and WESF, 300 Area Fuel Supply, K Basins, and program and environmental management.

The mission for Facility Operations plants has shifted from weapons material production to cleanup. Here are our mission goals:

- Deactivate facilities for transfer to the Surplus Facilities Management Program, using PUREX deactivation as a model for future facility deactivation at the Hanford Site and elsewhere

- Treat nuclear materiais as necessary for safe, long-term interim storage

- Achieve excellence in the conduct of operations and maintenance of nuclear facilities

- Complete an Environmental Impact Statement to select the preferred way to dispose of irradiated fuels stored at the Hanford Site.

\section{Objectives}

- In the $\mathrm{K}$ Basins, store the more than 2,100 metric tons of irradiated $\mathrm{N}$ Reactor fuel in a radiologically and environmentally safe condition.

- Maintain B Plant and WESF facilities and related buildings in a safe and environmentally sound condition until DOE-Headquarters directs us to remove the capsules and shut down the facilities.

- Keep PUREX and supporting facilities safe and in compliance with as little cost and effort as possible during the transition to a fully deactivated state.

- Maintain the 300 Area Fuels Supply facilities in compliance with applicable requirements until we receive direction and funding to begin deactivation of these facilities.

- At the PFP complex, store and handle special nuclear material, operate the labs that support PFP operations, handle other wastes, and do surveillance on shutdown facilities. We also will begin selected interim stabilization activities to reduce exposure and risk to the public and staff. We will do these activities in parallel with the NEPA process that will identify the acceptable alternatives for ultimate cleanup of the facility. 


\section{DOE/RL-94-37}

- Plan, report, and complete environmental compliance activities at PFP, PUREX, and the $\mathrm{UO}_{3}$ plant.

- Manage the resources and activities that are common to all Facility Operations plants.

\section{Major Milestones}

- Finalize project management plan 7/94, and organic and nitric disposition plans 4/94.

- Finalize the path forward for the interim storage of aluminum and $\mathbf{N}$-Reactor fuel $7 / 94$.

- Continue to safely store unirradiated $\mathbf{N}$-Reactor fuel and bullets.

- Continue to decontaminate building and equipment for disposal and turnover to decommissioning and decontamination.

- Implementation of closed-loop cooling completed ahead of schedule (M-17-16D) 1/94.

- Complete low-activity waste treatment facility 5/94.

- Complete tunnel radiation zone cleanup project 10/94.

- Receive safety analysis report approval and implement new operation safety requirements $6 / 94$.

- Initiate nitrate alternative investigation $6 / 94$.

- Initiate scrap stabilization activities $9 / 94$.

- Issue draft notice of intent for an environmental impact statement to determine future mission fo the Z-Plant and alternative processes for stabilizing and storage of Plutonium 4/94.

\section{Cost Baseline Summary}

The FY 1994 budget for Facility Operations is $\$ 182$ million, which is about a $27 \%$ decrease from the FY 1993 funding level. In addition DOE's Defense Program contributes $\$ 30$ million (which is not included in the Environmental Management Program total of $\$ 1524)$ for the safeguarding of on-site spent nuclear materials inventory. 
Mission

The Analytical Services program supports the Hanford Site mission by providing high quality analytical, field support, and process development services that meet all customer requirements. The overall Hanford Site mission and Tri-Party Agreement requirements guide this program. We will work with other Hanford programs to define their needs for Analytical Services, and we will use a combination of onsite and offsite analytical laboratories to meet those needs.

Analytical Services works directly with program customers to estimate the needed analytical support. This encompasses not only laboratory services but field sampling, field screening, mobile laboratories, and data. Two major projects under Analytical Services are the Waste Sampling and Characterization Facility and the expansion of the 222-S Laboratory hot cells. The WSCF supports the liquid effluent treatment facilities by providing sheet turn-around sample analyses. The 222-S and 325 Laboratories support analyses of highly radioactive samples such as tank samples from TWRS.

\section{Objectives}

- Ensure safe operations. Place special emphasis on operating within safety limits.

- Keep all onsite Analytical Laboratory facilities in a ready-to-serve condition (222-S, 325, WSCF, 2703E, 1706KE, field services).

- Provide budget and cost tracking and control systems.

- Do specific upgrades for capability or capacity requirements.

- Provide high-quality analytical services to Hanford program customers.

- Comply with applicable laws and regulations.

\section{Major Milestones}

- Maintain on-site laboratories ready-to-serve.

- Complete clean-out of hot cell at PNL laboratory.

- Start completion of new hot cell at Westinghouse laboratory.

- Start operation of new low-activity lab-waste sampling and characterization facility.

\section{Cost Baseline Summary}




\section{DOE/RL-94-37}

The FY 1994 budget for Analytical Services is \$51 million, which is about a $62 \%$ increase from the FY 1993 funding levels. Significant funding is also provided by the program customers for sample analysis services. 


\section{OTHER WASTE MANAGEMENT}

\section{RCRA \& Operational Monitoring Programs}

\section{Mission}

The mission of RCRA and Operational Monitoring Programs is to comply with the applicable monitoring regulations in a cost effective manner and to provide critically needed data for hazardous and radioactive waste management activities. This mission also covers monitoring radioactive air emissions and liquid effluents. We focus efforts on providing near-field monitoring to determine the effects of site activities on the environment immediately next to the site facilities and verify that measures to protect workers, the public, and the environment are effective. The program has primary responsibility for milestone M24-00, the installation of RCRA compliant groundwater monitoring. The remediation and decommissioning of wells is an important part of the mission.

\section{Planning Integration Program}

Mission

The mission for the Planning Integration Program is to lead and support effective planning by other Hanford Site programs. The Planning Integration Program will lead and coordinate the preparation of integrated, system-engineered plans and efficient workscope priority ranking methods that consider stakeholder values. This results in the implementation of baseline plans that are measurable and in priority order.

We will use effective management systems, methods, and standards to plan, organize, report, and control activities in a disciplined and efficient manner.

\section{Hanford Environmental Management Program}

Mission

The mission of the Hanford Environmental Management Program is to provide general support across the mission areas to ensure that Hanford Site facilities and programs comply with environmental requirements. Typical activities include preparing sitewide environmental reports and developing a sitewide NEPA strategy. 


\section{DOE/RL-94-37}

The specific program mission is to guide, coordinate, and integrate certain key environmental activities at the Hanford Site, including the following:

- Facility compliance with regulatory requirements

- Regulatory permitting and NEPA strategy

- Environmental reporting

- Pollution prevention

- Land Disposal Restriction status reporting

- Tri-Party Agreement integration

- Natural Resource Damage Assessment site coordination activities.

\section{Inventories}

\section{Mission}

The mission of the Hanford Site Inventories program is to manage, through teamwork, the Hanford Site's inventories using disciplined, safe, environmentally sound, and costeffective processes. These include implementing system contracts where possible, and identifying and setting up new inventory categories in support of waste management and environmental restoration activities. Inventory items include the following:

- Coal to meet steam requirements for the site

- Clean drinking water for the 200 and 300 Areas

- Essential materials and chemicals

- General supplies

- Computer hardware and software

- Fuel to keep fleet in operation

- Process spare parts for facilities and projects (Tank Farms and Labs) and fire systems maintenance

- Telecommunication spares for data systems essential to characterization activities.

\section{DOE-Richland Directed Activities}

A portion of the total Hanford Site budget is set aside to fund DOE-Richland federal field support employees and General Services Support Contractors, grants to the nearby tribal governments, oversight by Oregon's Department of Energy (not related to the federal DOE), and Tri-Party Agreement activities.

\section{Cost Baseline Summary}

The other Waste Management programs combine for a FY 1994 budget of $\$ 137$ million, which is about an $11 \%$ increase from the FY 1993 funding level. 


\section{LANDLORD PROGRAM}

\section{Mission}

The Hanford Site Landlord Program does the planning and work needed for general purpose facilities, equipment, and site infrastructure systems. It does this through identifying, evaluating, and funding work needed to safely carry out the Hanford Site mission.

The Hanford Site infrastructure is divided into 15 general systems that support Hanford activities on the 560-square mile site. Users identify needs based on plans that lay out mission requirements, building use and occupancy forecasts, systems studies, functional plans and goals, and maintenance schedules. We evaluate this input and set priorities based on criteria consistent with those in other Hanford planning documents, putting top priority on worker and public safety and environmental compliance.

Many factors guide infrastructure development. First come safety and meeting regulations. Our other guidelines are to deliver an infrastructure that meets the Hanford Site cleanup and other mission needs and does so in manner that's cost-effective manner, has value after cleanup ends for other missions. We strive to concentrate service locations by grouping activities, upgrading or demolishing inadequate and underused facilities, promoting energy-efficient facilities, and maintaining facilities and equipment as economically and safely as possible.

\section{Objectives}

- Identify future infrastructure needs to support the Hanford Site cleanup and other missions through infrastructure system studies and alternative analyses. Integrate Landlord Program planning with other program plans so needed infrastructure systems in a cost-effective and safe manner, and to evaluate current and future needs to use limited resources effectively.

- Develop a reliable and meaningful process for inspections, reporting and estimating costs.

- Develop the Landlord input to the FY 1996 Capital Asset Management Program (CAMP) report. The report represents key information used in fiscal planning of projects and capital asset modification and serves as a key reference document.

- Continue to streamline the process of authorizing projects to reduce development costs and respond more quickly to the Hanford Site construction needs. 
- Evaluate whether to use with the private sector or local utilities for new Hanford Site infrastructure facilities and services, rather than building them ourselves. Coordinate the facilities and services that will potentially be provided by others with the International Environmental Institute.

- Develop an automated base mapping configuration control system, and acquire and maintain base map information in geographical information system format. Develop a prototype to test and select software and acquire site expertise, moving toward full implementation in FY 1995.

\section{Major Millestones}

- Complete underground storage tanks project.

- Begin to lease parcels of land in 300 Area to the city for economic transition.

- Construct SR 240 access road.

- Install packarge boiler in 200 West.

- Demolish unoccupied surplus facilities, (2724-W, WA \& WB).

- Complete construction on Phase I 300 Area electrical distribution system.

- Complete upgrade of fire water storage and distribution in 300 Area.

- Complete demolition of 3000 Area buildings

\section{Cost Baseline Summary}

The FY 1994 budget for the Landlord Program is $\$ 51$ million, which is about an 18\% decrease from the FY 1993 funding level. 
Mission

The Advanced Reactor Program does the planning and activities for placing the FFTF in a safe shutdown condition. During the transition period, we will maintain facilities and systems in a safe and environmentally sound condition. We also will prepare facilities that were associated with the DOE-Headquarters' Office of Nuclear Energy Programs, and that are no longer used, for appropriate disposition.

\section{Objectives}

- Maintain the FFTF, Fuels and Materials Examination Facility, 308 Building, and related facilities.

- Complete the cleanup of the 308 Building and place the building under minimal surveillance.

- Continue managing the equipment and buildings left over from our former involvement in the Office of Nuclear Energy Programs, per Ecology requirements and funding and priorities from DOE.

- Conduct processing activities in the Interim Examination and Maintenance Cell (delayed neutron signal assembly).

- Promptly close out earlier activities that supported possible new FFTF missions.

- Defuel the FFTF.

\section{Major Milestones}

- Complete planning documentation and commence shutdown.

- Initiate definitive design of the sodium storage facility.

- Submit National Environmental Policy Act (NEPA) documentation for FFTF shutdown.

- Close 308 building process area to all entry except surveillance.

- Ship 75 - 55 gallon drums of sodium from Gable Mountain to off-site vendor for recycle.

\section{Cost Baseline Summary}

The FY 1994 budget for Advanced Reactor is \$62 million, which is about a $1 \%$ increase from the FY 1993 funding level. 
DOE/RL-94-37

This page intentionally left blank. 
Mission

The Environmental Restoration mission is divided into five summary subprojects:

(1) Remedial Action, (2) Decontaminating and Decommissioning, (3) Program Management Support, (4) Surveillance and Maintenance, and (5) Disposal Facilities. DOE established this program in 1987 to plan, carry out, and control remediation and Decontaminating and Decommissioning efforts. The mission also includes the surveillance and maintenance of deactivated Hanford facilities and facilities transferred to the surplus facilities management program until decontaminating and decommissioning has been completed.

\section{Objectives}

- Ensure safe operations.

- Comply with laws and regulations to protect human health and the environment.

- Manage all past practice radioactive, hazardous, mixed, and sanitary waste to protect human health and the environment.

- Develop and implement programs and projects that minimize the generation of waste through material and product substitutions, recycling, administrative controls, and stimulating the development of more modern materials processing methods.

- Carry out a strong quality assurance program to improve the efficiency and effectiveness of environmental restoration programs and document achievements of quality assurance requirements.

- Reduce overhead and infrastructure costs.

- Complete projects underway in FY 1994 on schedule, unless delays are consistent with priorities.

- Consider the placement of work in the private sector whenever practical.

- Support the ongoing commitments to Washington State, the Indian Nations, and the overall Hanford Site long-range integrated planning effort. 


\section{DOE/RL-94-37}

- Plan all past-practices activities in accordance with the newly updated TriParty Agreement and the anticipated changes to that agreement through the efforts to refocus the Environmental Restoration program. DOE, Ecology and EPA agreed refocus these activities to start and finish of remedial actions earlier and speed up remediation of sites along the Columbia River and next to the City of Richland.

In order to accomplish this, the three parties will reevaluate that parts of the environmental restoration program they didn't cover in the recent renegotiations. The parties agreed to examine options, consult with the public, and end negotiations by September 30, 1994 on a new course of action for more timely and effective environmental restoration cleanups. During these negotiations, the current schedule for environmental restoration work remains in place unless the three parties otherwise agree on a case-by-case basis.

- Consider the infrastructure required to support the current and recently negotiated scopes of work in planning upgrades to facilities and equipment.

- Establish productivity improvement targets.

- Provide near-term disposal capabilities (e.g., Radioactive Mixed Waste Disposal Facility to support scheduled interim remediation actions and expedited response actions.

- Complete definition of long-range disposal requirements and proceed with facility designs.

\section{Major Milestones}

- Complete 2 records of decision.

- Continue carbon tetrachloride extraction activities.

- Complete 185/190-B complex demolition.

- Compelete construction of 200-BP-1 prototype barrier.

- Complete decontamination of 100-HR Basin surface.

- Complete Environmental Restoration Disposal Facility conceptual design.

- Reduce areas of surface contamination.

- Stabilization of contaminated facilities such as ditches and retention basins.

- Removal of four underground storage tanks.

- Ongoing technology developments: 


\section{DOE/RL-94-37}

- In Situ Chemical Treatment

- Hanford Site barrier

- In Situ Vitrification Spot melt

- Support liquid membrane

- Geophysical logging.

- Complete draft Hanford Site remedial action environmental impact statement.

\section{Cost Baseline Summary}

The FY 1994 budget for Environmental Restoration is $\$ 197$ million, which is about a $11 \%$ increase from the FY 1993 funding level. This budget could be increased to $\$ 217$ million if a reprogramming effort is successful. 
DOE/RL-94-37

This page intentionally left blank. 


\section{TECHNOLOGY DEVELOPMENT NATIONAL PROGRAM}

Mission

The Hanford Technology Development Program is part of the DOE-Headquarters Office of Technology Development National Program. That National Program, in cooperation with other DOE research organizations, will use the best science and technology available to solve the most challenging set of environmental problems in the world. By applying principles of Total Quality Management and strategic planning, DOE will achieve measurable progress in developing and applying technology to support the EM mission in the most cost-effective and timely fashion. Hanford's Technology Coordination Group will maintain a close interface with the National Program to ensure that Hanford Site needs are addressed effectively and that local efforts support national needs.

\section{Objectives}

- Help identify Hanford Site operational needs and communicate them to the national program.

- Propose, conduct, and manage Hanford Site technology development tasks that meet Hanford Site and complex-wide needs.

- Transfer appropriate technologies to operations at the Hanford Site from the national program and other DOE sites.

- Support the national program.

\section{Major Milestones}

- Complete demonstration and transfer of integrated drilling and vapor extraction systems.

- Light duty arm procurement.

- Support tank C-106 retrieval mission.

- Conduct small business exchange workshops.

\section{Cost Baseline Summary}

The FY 1994 budget for Technology Development is $\$ 63$ million, which is about a $31 \%$ decrease from the FY 1993 funding level. This decrease is because of the transfer of the Environmental Molecular Science Laboratory from Environmental Management (EM) to Energy Research (ER). 
DOE/RL-94-37

This page intentionally left blank. 


\section{Mission}

The Science and Technology Research Support Program focuses on management of current and newly generated wastes, monitoring of the Hanford Site environment, and remediation of facilities and environmental media contaminated as a result of past actions.

\section{Objectives}

- Conduct operations in a safe and responsible manner, managing all wastes generated in compliance with regulatory requirements.

- Independently assess the impact of Hanford Site operations on the environment to ensure the safety of the public and Hanford Site workers.

- Remediate waste stored on the site from previous Hanford Site operations to ensure compliance with environmental, safety, and health requirements.

\section{Major Milestones}

- Complete Hanford Site Environmental Report for CY 1993 by 6/1/94.

- Complete successful annual disposal of Pacific Northwest Laboratory's hazardous wastes by $9 / 30 / 94$.

- Conduct Pacific Northwest Laboratory's liquid effluent sampling program by 9/30/94.

- Complete remote visual inspection of hazardous waste tanks within room 40A of the 325 Building by $9 / 30 / 94$.

- Have $63 \%$ of the 324 Building B-Cell floor area cleaned and complete $70 \%$ of cleanout by $9 / 30 / 94$.

\section{Cost Baseline}

The FY 1994 budget for Science and Technology Research is $\$ 35$ million, which is about an 18\% increase from the FY 1993 funding level. 


\section{INTERNATIONAL ENVIRONMENTAL INSTITUTE}

\section{Mission}

The International Environmental Institute (IEI), an organization within Westinghouse Hanford Company (WHC), was formed in 1992 to leverage the "lessons learned" during Hanford cleanup to help others around the nation and world benefit from the work and research being done here. The IEI is involved with planning, developing, acquiring, testing, and implementing environmental technologies and processes. The IEI also is interested in cooperative efforts with other entities to commercialize technologies developed for use at Hanford, and to redeploy, loan or lease those assets of the Site that are no longer needed by the Department of Energy.

\section{Service Offering}

The International Environmental Institute matches private sector and industrial interests with the needs and opportunities associated with the environmental cleanup and conversion of the Hanford Site.

\section{Key Technologies and Services}

Technology Acquisition and Commercialization

Asset Conversion

Privatization

International Environmental Training and Student Exchange Programs

\section{Marketing Strategy}

The International Environmental Institute (IEI) represents the needs of Westinghouse Hanford Company in seeking new and innovative technologies to assist the environmental cleanup mission of the Hanford Site. Industrial interactions with the Site could be accomplished through a range of mechanisms including standard procurements, Cooperative Research and Development Agreements, other partnership arrangements, and licensing of Hanford-developed technologies for commercialization. The IEI is also working to redeploy, loan or lease some of the existing assets of the Site to other businesses or entities who have an interest in locating in the region. 


\section{Service Profiles}

Technology Acquisition and Commercialization:

The International Environmental Institute within Westinghouse Hanford Company aggressively seeks to match the technology needs of the Hanford cleanup mission with the capabilities of private industry. These technologies and processes are required to support characterization, monitoring, stabilization, retrieval, processing, and disposal of hazardous and radioactive wastes at the Hanford Site. The IEI also negotiates technology license agreements, provides direct contact with the developers of technologies and offers other assistance in accessing technologies developed and demonstrated at the Hanford Site. Current licensable technologies include laser ablation, fiber optic chemical sensors, venting and gas sampling retrieval system for waste-containing drums, and specialized hazardous environment protective clothing. Partnerships with private industry also include mechanisms such as Cooperative Research and Development Agreements, technical assistance, staff exchanges, workshops and other programs.

Asset Conversion:

The International Environmental Institute organization within WHC works to identify and redeploy unused or underutilized Hanford assets. Hanford's asset base includes 1450 square-kilometers (560 square miles) of land, including roads, railroads and utilities; more than 1,000 buildings; a wide array of equipment ranging from specialized technical tools, to computers and laboratory equipment; and a well-trained and highly-skilled workforce. The goal is to provide economic or social value for surplus assets by identifying business opportunities for the regional community, and public and private enterprises. The IEI works to match external entities' physical and human resource requirements with these surplus Site assets. Current asset conversion activities include the development of aquaculture programs in the inlet basins, the transfer of metalworking equipment to the City of Richland for the establishment of a local commercial metalworking company, the establishment of an industrial park on the Hanford Site, and the loan of excess welding equipment to the local community college to supplement their training programs.

\section{Privatization:}

A major goal of the International Environmental Institute is to identify and encourage opportunities for private sector involvement in environmental restoration and other cleanup activities at the Hanford Site. The IEI works to identify Hanford's environmental technology needs and potential private sector providers, and also tries to match private firms seeking business at Hanford with the appropriate organizations within WHC and the Department of Energy. Completed and ongoing privatization activities include procurements for decontamination laundry services, carbon tetrachloride vapor extraction, thermal treatment of low-activity mixed waste, carbon dioxide decontamination cleaning, solid waste disposal, waste volume reduction, high-activity and low-activity waste vitrification, radioactive sodium treatment and disposal, and nondestructive examination and assay. 


\section{DOE/RL-94-37}

International Environmental Training and Student Exchange Programs:

The International Environmental Institute is involved with maintaining a continuous supply of well-educated and trained workers to help with the Hanford Site cleanup and with other environmental restoration sites around the nation and world. The student intern center within the IEI is adept at providing quality on-the-job experiences at the Hanford Site for future professionals in the environmental fields. The IEI works with other national and international entities to set up cooperative education programs and on-site assignments for university professors and students. The focus on training is carried through to the present workforce as well. The Hanford Site has some of the most in-depth and well developed environmental training courses and the IEI seeks to share these resources with other entities. One of these resources is the new Hazardous Materials Management and Emergency Response (HAMMER) Training Center recently authorized by the U.S. Congress. HAMMER is a state-of-the-art training complex which will incorporate performance-based, hands-on training for both the public private industry in hazardous materials, occupational safety and emergency response. 


\section{EMPLOYMENT PROJECTIONS FOR THE HANFORD SITE}

Hanford employment, excluding subcontractors, is projected to remain relatively stable at the current level of approximately 17,800 .

However, during calendar year 1994, the DOE-RL and some of its major contractors will undertake a number of initiatives that will result in restructuring the contractor work forces. We are taking these initiatives to improve the cost effectiveness and efficiency of operations. Between 500 and 1000 jobs could be eliminated by these actions. DOE-RL will consult with workers and other stakeholders in the development of a work force restructuring plan to mitigate the impact of these actions on affected workers.

Initiatives that will lead to work force restructuring but which seek to reduce costs and help assure the economic viability of the Tri-Cities region include:

- Privatization of site operations now being carried out by Hanford Site contractors

- Implementation of new contracting arrangements

- Realignment of the Westinghouse Hanford Company management structure

- Elimination of duplicative activities of WHC and its subcontractor, Kaiser Engineers Hanford Co., through the merger of some elements of their staffs

- Implementation of new business practices resulting from the Reinventing Government initiative and the Tri-Party Agreement cost initiative.

In addition, some minimal work force restructuring actions may be necessary from time to time in the Pacific Northwest Laboratory because of changes in national priorities or tasking from program sponsors.

The National Defense Authorization Act for Fiscal Year 1993 (Public Law 102-484) requires the Secretary of Energy to develop a work force restructuring plan in consultation with stakeholders to mitigate the impact on workers and communities of work force changes at the DOE's current or former defense nuclear facilities. DOE-RL will consult with stakeholders to prepare a workforce restructuring plan for calendar year 1994. The plan will minimize involuntary lay-offs and to help affected workers. The plan will also address potential economic development opportunities that may help mitigate the impact of job losses on the local community. 


\section{DOE/RL-94-37}

This page intentionally left blank. 


\section{DOE/RL-94-37}

\section{FY 1995 CONGRESSIONAL BUDGET REQUEST}

The total Hanford Site FY 1995 Congressional Budget Request of $\$ 2.05$ billion is about the same level as that requested for FY 1994. Of the total Hanford Site budget, $\$ 1,691$ million (or 82\%) is for the Environmental Management Program activities. This requested budget level of $\$ 1,691$ million is subject to change as a result of DOEHeadquarters decisions on the funding of improvements to productivity and the use of money not spent in FY 1994. The actual budget level also is contingent upon Congressional appropriations and Presidential approval.

The FY 1995 budget request for Hanford Site will support the recently signed revisions to the Tri-Party Agreement. The FY 1995 Congressional budget request for the Hanford Site will provide continued support for major Hanford Site activities. Some of these major activities are described below:

- Continue implementation of TWRS key safety initiatives

- Begin pumping and interim stabilization of four single-shell tanks

- Start definitive design of the Initial Pretreatment Module in anticipation of a 1998 construction start

- Continue construction of six new double-shell tanks

- Start operation of treatrient and disposal facilities for Phase I liquid effluent, streims in the 200 and 300 Areas, which will end the practice of discharging those intreited liquids to the ground

- Start deĩnitive design on treatment and disposal facilities for Phase II liquid effluent streams

- Continue interim actions to reduce dose exposure and risk to both worker and public, pending the record of decision on the Environmental Impact Statement for final disposition of material in PFP

- Continue PUREX deactivation (complete this activity in FY 1998)

- $\quad$ Reduce safety risks at K-East Basin by continuing encapsulation of irradiated fuel (complete this activity in FY 1996)

- Complete detailed shutdown plans for FFTF, continue defueling the reactor, and begin fuel washing (complete the shutdown in FY 1999)

- Implement a new strategy in the Environmental Restoration program to clean up groundwater and sites along the Columbia River faster

- Continue building the Environmental Molecular Sciences Laboratory (complete this activity in FY 1997)

- Begin building the Hazardous Materials Management and Energy Response Emergency Management Training Center (complete this activity in FY 1997) Continue developing the Hanford Transition Program Office to ensure that everything done at the Hanford Site is competitive with the best commercial practices and adds value to DOE missions. 
Throughout the continued development of the FY 1995 EM Program planning, We are committed to the increased involvement of state and federal regulators and other stakeholders in the as we set program goals, schedules, priorities and funds allocation.

The Activity Data Sheets have greater detail about the work we described in this report. Copies of these ADSs are in the Hanford Tri-Party Agreement Information Repositories. The locations for these repositories are as follows:

University of Washington Suzzallo Library Government Publications Room Mail Stop FM-25 Seattle, WA 98195 (206) $543-4664$

ATTN: Eleanor Chase

Gonzaga University Foley Center E. 502 Boone Spokane, WA 99258 (509) 328-4220 EXT 3125 ATTN: Lewis Miller
Portland State University Branford Price Millar Library Science and Engineering Floor SW Harrison and Park P.O. Box 1151

Portland, Oregon 97207 (503) 725-3690

ATTN: Michael Bowman

USDOE Reading Room

Washington State University, Tri-Cities

100 Sprout Road, Room 130

Richland, WA 99352

(509) 376-8583

ATTN: Terry Traub 


\section{LIST OF TERMS}

$\begin{array}{ll}\text { AAMSR } & \text { Aggregate area management study reports } \\ \text { ALARA } & \text { As low as reasonably achievable } \\ \text { CY } & \text { calendar year } \\ \text { D\&D } & \text { Decontaminating and Decommissioning } \\ \text { DOE } & \text { U. S. Department of Energy } \\ \text { ECOLOGY } & \text { Washington State Department of Ecology } \\ \text { EPA } & \text { U.S. Environmental Protection Agency } \\ \text { ER/WM } & \text { Environmental Restoration and Waste Management } \\ \text { ERMC } & \text { Environmental Restoration Management Contractor } \\ \text { FFTF } & \text { Fast Flux Test Facility } \\ \text { FY } & \text { Fiscal Year } \\ \text { HAMMER } & \text { Hazardous Materials Management and Emergency Response } \\ \text { LDR PLAN } & \text { Land disposal restrictions plan for mixed wastes } \\ \text { NEPA } & \text { National Environmental Policy Act } \\ \text { NRDA } & \text { Natural Resource Damage Assessment } \\ \text { PFP } & \text { Plutonium Finishing Plant } \\ \text { PFP } & \text { Plutonium Finishing Plant } \\ \text { Project W-113 } & \text { Contact Handled-Transuranic Retrieval } \\ \text { Project W-112 } & \text { Enhanced Radioactive Mixed Waste Storage } \\ \text { PUREX } & \text { Plutonium-Uranium Extraction } \\ \text { RFI/CMS } & \text { RCRA Facility Investigation/Corrective Measures } \\ \text { RI/FS } & \text { Remedial investigation/feasibility studies } \\ \text { RI } & \text { Remedial Investigation } \\ \text { TRI-PARTY } & \\ \text { AGREEMENT } & \text { Hanford Federal Facility Agreement and Consent Order } \\ \text { TRU } & \text { Transuranic } \\ \text { TWRS } & \text { Tank Waste Remediation System } \\ \text { URANIUM } & \text { Converted liquid uranyl } \\ \text { WESF } & \text { Waste Encapsulation and Storage Facility } \\ \text { WESF } & \text { Waste Encapsulation and Storage Facility } \\ \text { WRAP I } & \text { Waste Receiving and Processing-Module I facility } \\ \text { WSCF } & \text { Waste Sampling and Characterization Facility } \\ & \end{array}$


This page intentionally left blank. 


\section{DOE/RL-94-37}

\section{GLOSSARY}

101-SY (formally known as 241-SY-101)--The double-shell tank, located in the 200 West Area, that generates the largest amount of combustible hydrogen and nitrous oxide gases. Periodically gases that have accumulated underneath a crust on top of the waste are released or "burp," pushing through and rolling over portions of the crust.

200 Areas--The section of the Hanford Site, near its center, used to reprocess irradiated nuclear fuel and store the resulting wastes. The 200 Areas is divided into two sections: 200 East Area and 200 West Area.

200 Areas Effluent Treatment Facility--A facility now under construction that will treat low-activity radioactive and hazardous liquid wastes from 200 Area plants before they are discharged.

Aggregate Area Management Strategy--A way to clean up old waste sites faster if information shows this would reduce risks to the public and environment. Existing information would be gathered and studied. If it suggested early actions would help, we would take interim actions. We also would deal with the source of the contamination and the groundwater unit at the same time, to take care of the highest risks first.

300 Area--The section in the southern part of the Hanford Site on the Columbia River used for laboratory work and fabrication of the nuclear fuel used by the reactors.

Arid Lands Ecology Reserve--The western part of the Hanford Site, a 124-squaremile area that has been relatively undisturbed by human development for almost 50 years, to which access is limited for scientific purposes. Its boundaries are the crest of Rattlesnake Ridge to the west, Highway 240 to the east, and Highway 24 to the north.

As Low As Reasonably Achievable (ALARA)--A radiation protection principle applied to radiation exposures, with costs and benefits taken into account.

B Plant--A Hanford Site facility built in 1943 to recover plutonium for nuclear weapons. It used first-penetration technology (bismuth-phosphate process). This mission ended in 1956. After modifications, B Plant restarted in 1967 for its second mission, which was to remove strontium and cesium from stored liquid wastes.

Baseline--A reference value. At the Hanford Site, we use it to mean our plans for cost, schedule, and performance.

Best Available Technology or Best Demonstrated Available Technology--Treatment technologies that have been shown through actual use to yield the greatest environmental benefit among competing technologies that are practically available. 


\section{DOE/RL-94-37}

Characterization--Facility or site sampling, monitoring, and analysis activities to determine the extent and nature of the waste problem at a site. Characterization provides the basis for getting the technical information required to develop, screen, analyze, and select appropriate cleanup techniques.

Cleanup-Actions taken to deal with the release, threatened release, or management of hazardous materials that could affect public health or the environment or both. The term "cleanup" is often used broadly to describe various response actions, phases of remedial responses, or waste management activities.

Comprehensive Environmental Response, Compensation, and Liability Act (CERCLA)-Also known as Superfund, this is the Federal law enacted in 1980 and reauthorized in 1986 that gives statutory authority for cleanup of hazardous substances at formerly used sites that could endanger public health or welfare or the environment.

Conceptual Design Report--A report engineers prepare to describe how to meet the needs defined in a functional design criteria report, and that forms the basis for preliminary cost estimating for a facility or machine. (see functional design criteria)

Condensate--Liquid that is boiled off, then condensed back into a liquid, or that results from condensing a gas.

Contamination--Measured concentration of an undesirable chemical (radioactive or not) that is above the normal or background level.

Corrective Actions--Measures taken under RCRA or CERCLA to clean up a waste site. Corrective actions also are taken to close safety issues.

Decommissioning--The process of permanently closing a nuclear facility to provide adequate protection from radiation exposure and to isolate radioactive contamination from the human environment. Actions taken to reduce the potential health and safety impacts of U.S. Department of Energy (DOE) - contaminated facilities, including activities to stabilize, reduce, or remove radioactive materials or to demolish the facilities.

Decontaminating and Decommissioning (D\&D)--The process of removing contamination from facilities or equipment by washing, chemical action, mechanical cleaning, or other techniques, then removing the facility or equipment from operation, and entombing, dismantling and removing, or converting the facility or equipment for another use.

Disposal--Waste emplacement designed to ensure isolation of waste from the biosphere with no intention of retrieval in the foreseeable future and that requires deliberate action to regain access to the waste. 


\section{DOE/RL-94-37}

DOE Orders--Internal requirements that establish DOE policy and procedures for compliance with applicable laws and regulations.

Double-Shell Tank--A large reinforced concrete underground container with two inner steel liners to provide containment and backup containment of liquid wastes. The space between the liners has instruments to permit detection of leaks from the inner liner.

Effluent-A stream or flow of discharged material (e.g., into the environment, tanks, treatment systems).

Environmental Impact Statement--A document required by the National Environmental Policy Act that assesses the environmental impacts of proposed federal actions, rather than justifying decisions already made. It reviews alternatives to proposed actions, characterizes impacts, identifies unavoidable impacts and irreversible or irretrievable commitments to resources, and describes short-term effects and long-term productivity.

Environmental Restoration--Cleanup and restoration of sites contaminated with hazardous substances during past production or disposal activities.

Evaporator-A Hanford Site facility that reduces the water content in tank waste to concentrate the waste and reduce storage space needs.

Fast Flux Test Facility (FFTF)--A liquid metal test reactor that serves as a test tool for advanced reactor technology. Operations at the FFTF began in 1982 and were expanded into other areas, such as fusion research, space power systems, and isotope production.

Feasibility Study--A step in the environmental restoration process specified by CERCLA. The objectives are to identify the alternatives for remediation and to select and describe a remedial action that satisfies the applicable or relevant and appropriate requirements for mitigating confirmed environmental contamination. Successful completion of the feasibility study should result in unimpeded subsequent development of a remedial design for implementing the selected remedial actions.

Geologic Repository--A mined facility for disposal of radioactive wastes that uses natural geologic barriers to provide waste containment over geologic time scales.

Groundwater--Liquid water occurring beneath the earth's surface, in the intervals between soil grains in fractures or in porous formations.

Groundwater Remediation--Treatment of groundwater to remove pollutants. 


\section{DOE/RL-94-37}

Grout--As the term is used at the Hanford Site, a fluid mixture of cementitious materials and liquid waste that sets up as a solid mass and is used to fix and immobilize waste. This is the treatment of choice of the EPA to immobilize certain chemical wastes. The Hanford Grout Treatment Facility will be regulated under the RCRA program.

Hazardous Wastes--Those wastes included in the definitions of RCRA 1004(5) and the Revised Code of Washington 70.105.010(15).

High-activity Waste--Highly radioactive waste material that results from the reprocessing of spent nuclear fuel, including liquid waste produced directly in reprocessing and any solid waste derived from the liquid, that contains a combination of TRU waste and fission products in concentrations requiring permanent isolation.

Hot Cell--An enclosed area that is sealed and shielded for work with radioactive materials. Workers outside the area use remote manipulators to handle the material inside.

Interim Stabilization--Transferring liquids to the double-shell tanks that can be removed from the single-shell tanks.

K Basins--Water-filled storage basins in the $100 \mathrm{~K}$ Area in which irradiated fuel from $\mathrm{N}$ Reactor is stored. The two basins are $100 \mathrm{~K}$ East and $100 \mathrm{~K}$ West.

Land Disposal Restrictions--Provisions of the Hazardous and Solid Waste Amendments to RCRA that require hazardous wastes to be treated before being disposed of in the ground.

Low-activity Waste--All radioactive waste that has not been classified as high-activity waste, TRU waste, spent nuclear fuel, or byproduct material.

Milestone--The date by which specified work needs to be completed.

Mixed Waste--Waste with both radioactive and hazardous components, as defined by the Atomic Energy Act and the RCRA. Mixed wastes are regulated under both laws.

N Reactor--The last plutonium production reactor built at the Hanford Site. It operated from 1964 to 1987 . It is shut down and no restart is planned.

National Environmental Policy Act (NEPA)--A law that established the requirement for conducting environmental reviews of Federal actions that have the potential for significant impacts to the human environment.

Natural Resource Damage Assessment (NRDA)--An assessment of damages to a natural resource resulting from the release of CERCLA hazardous substances. 


\section{DOE/RL-94-37}

North Slope--The area of the Hanford Site north and east of the Columbia River. Also called the Wahluke Slope. Part of this 189-square mile area is now administered by the U.S. Fish and Wildlife Service as a wildlife preserve, and the State Department of Wildlife administers the rest for daytime recreational use and some livestock grazing.

Operable Unit--A discrete portion of a site consisting of one or more release sites considered together for assessment and cleanup activities. The major reasons to place release sites together in an operable unit include geographic proximity, similarity of waste characteristics and site type, and the possibilities for cost savings because of the proximity and similarities of the site.

Past-Practice Units--Areas within the Hanford Site where solid wastes were buried or liquid wastes were discharged to the ground in the past.

Past-Practices Strategy--A new strategy for streamlining the past-practice corrective action process by (1) accelerating decision making by maximizing the use of existing data consistent with data quality objectives and (2) undertaking Expedited Response Actions and/or interim response measures as appropriate to either remove threats to human health and welfare and the environment or to reduce risk by reducing toxicity, mobility, or volume of contaminants.

Plutonium Finishing Plant (PFP)- A complex in the 200 West Area where plutonium from scrap material is stabilized and recycled for reuse. Until 1989, the plant processed plutonium nitrate from the PUREX Plant to make plutonium metal for shipment elsewhere for use in weapons.

Plutonium-Uranium Extraction (PUREX)--Third-generation technology to separate plutonium from irradiated fuel. At the PUREX Plant, irradiated fuel was chemically dissolved from 1956 to 1972 and again from 1983 to 1989 to recover plutonium and uranium.

Pretreatment--As the term is used at the Hanford Site, the treatment of double-shell tank wastes before they are solidified by vitrification. Present plans call for the wastes to be pretreated to separate the high volume of low-activity waste from the low volume of high-activity waste (to be vitrified).

Privatization--Using the commercial sector for services usually performed by the government or its contractors.

Quality Assurance--Planned and systematic actions necessary to provide adequate confidence that a structure, system, or component will perform satisfactory in service. Quality assurance includes quality control.

Radiation--Energy in the form of waves or particles from parts of atoms. 


\section{DOE/RL-94-37}

Radioactive Waste--A solid, liquid, or gaseous material of negligible economic value that contains radionuclides in excess of threshold quantities.

Radionuclides--Radioactive nuclides. A nuclide is a species of atom with a specific mass, atomic number, and nuclear energy state.

RCRA Facility Assessment--The initial RCRA process to determine whether corrective action for an RCRA past-practice unit is warranted or to define what additional data must be gathered to make this determination; analogous to a CERCLA Preliminary Assessment and Site Inspection.

Remedial Investigation (RI)--The CERCLA process of determining the extent of hazardous substance contamination and, as appropriate, conducting treatability investigations. The RI provides the site-specific information for the feasibility study.

Remedial Investigation/Feasibility Study (RI/FS)--The process under CERCLA to study the site needing cleanup, and identify, evaluate, and select a cleanup option that complies with the law.

Remediation--Correcting a condition, such as by removing or isolating contaminated material.

Reprocessing--The dissolution of spent reactor fuel and separation of uranium, TRU elements, and fission products.

Resource Conservation and Recovery Act (RCRA)--A Federal law enacted in 1976 that regulates generation, transportation, treatment, storage, and disposal of hazardous wastes and remediation of waste sites currently in use (contrast with CERCLA).

Safety Analysis Report--A report that documents the adequacy of safety analyses for a nuclear facility to ensure that the facility can be built, operated, maintained, shutdown, and decommissioned safely and in compliance with applicable laws and regulations.

Senior Executive Committee--A committee consisting of the Manager of DOE-RL, the director of the Washington State Department of Ecology, and the Administrator of EPA Region 10, which meets to discuss top-level Tri-Party Agreement issues.

Single-Shell Tanks--At the Hanford Site, underground reinforced concrete containers with one carbon steel liner. The tank is covered with 2 to 3 meters of earth. Capacity ranges from 209,000 to 3.8 million liters (55,000 to 1 million gallons). The tanks have been used to store high-activity radioactive wastes. 
Site Wide Systems Analysis--An analysis of Hanford Site waste management and environmental restoration needs using a process called systems engineering.

Special Nuclear Material--Atoms than can be fissioned (split to sustain a nuclear chain reaction), such as plutonium.

Stakeholder-An individual or group who could affect or be affected by decisions.

Storage-Retention and monitoring of waste in a retrievable manner pending final disposal.

Surplus Facility--Any facility or site (including equipment) that has no identified programmatic use and may or may not be radioactively contaminated to levels that require controlled access.

Systems Engineering--A formalized, integrated, logical approach to decision making. It requires the clear identification of values; then technical experts rank the performance of alternatives for any one value dimension (for example, "cost effectiveness").

T Plant--One of the original processing plants built in 1943 to separate plutonium for use in bombs. Now the facility is used for D\&D equipment.

Tank Farm--An installation of multiple adjacent tanks, usually interconnected, to store liquid waste or substances used in Hanford Site operations. Tank farms at the Hanford Site are underground.

Transuranic (TRU)--Having radionuclides with an atomic number greater than that of uranium, with a half-life of more than 20 years, and in concentrations greater than 100 nanocuries per gram of waste. In lay terms, TRU wastes are usually those contaminated with plutonium. Most do not have much penetrating radiation--a piece of paper or 5 centimeters ( 2 inches) of air is all the shielding one would need--but they need to be isolated because they typically remain radioactive for long periods of time.

Treatment--Any activity that alters the chemical or physical nature of a hazardous waste to reduce its toxicity, volume, mobility or render it amenable for transport, storage, or disposal.

Tri-Party Agreement--An agreement signed by Ecology, U.S. Environmental Protection Agency, and DOE that identifies milestones for key waste management actions.

TSD--Treatment, Storage, and Disposal. 


\section{DOE/RL-94-37}

UO $_{3}$ Plant-The Uranium Trioxide Plant, which is a processing facility that converted liquid uranyl (uranium) nitrate hexahydrate from the PUREX Plant into a uranium trioxide powder that was recycled into reactor fuel. The plant was built in 1943-44 and operated from 1951 to 1972 and again from 1984 to 1989.

Vitrification--Forming a glass-like material by heat and melting.

Waste Encapsulation and Storage Facility (WESF)--The building next to B Plant in which radioactive strontium and cesium were doubly encapsulated in stainless steel capsules and are stored underwater.

Waste Management--Activities involving the short-term or long-termm storage or isolation of existing or newly generated wastes, treatment and final disposal of wastes.

Waste Receiving and Processing Facility--A plant to be built at the Hanford Site that will receive, repackage, certify, sort, treat, and reduce volume for low-activity, TRU, low-activity mixed, and TRU mixed wastes (not all functions for all waste types). TRU wastes will be shipped offsite for disposal from this facility.

WRAP Module I--The first phase of the Waste Receiving and Processing Facility. It will include nondestructive testing services, examination, certification, and shipping of boxes and drums of contact-handled TRU waste, opening and repackaging of TRU drums, and decontamination of drum overpacks and items that could fit inside drums.

WRAP Module II--The second phase of the Waste Receiving and Processing Facility. It will treat and handle low-activity mixed wastes, remote-handled wastes, and decontamination of larger items. It also will process retrieved and newly-generated remote-handled TRU waste and all low-leve mixed waste and secondary solids.

Waste Stream--The waste that leaves a facility or operation; similar to effluent.

Watch List--A list of the Hanford Site single- and double-shell underground waste storage tanks that have identified safety issues. This list is required by Public Law 101-510, Section 3137(a), which requires the identification and aggressive management of tanks that pose a serious risk of explosion. Tanks on the Watch List have issues with flammable gas generation, high heat loads, organic compounds, and ferrocyanide contents.

Work Breakdown Structure--A product-oriented hierarchical depiction of the activities and products necessary to complete a program or project. It subdivides the work to a manageable level where work is planned, responsibility is assigned, work is controlled and executed, and performance is measured. 


\section{TRI-PARTY AGREEMENT MAJOR MILESTONES}

Number Milestone

M-11-00 Complete construction and initiate operations of expanded laboratory hot cells for high-activity radioactive mixed waste.

M-12-00 Submit remedial investigation/feasibility study (RI/FS) or RCRA Facility Investigation/ Corrective Measures Study (RFI/CMS) work plans for 15 operable units.

M-13-00 Submit six RI/FS or RFI/CMS work plans per year between 1/1/93 and 12/31/99.

M-14-00 DOE shall comply with senior executive committee agreement on resolution of Milestone M-14-00 change request dispute (dated 1/8/93). (Formally titled "Complete Construction and Initiate Operations of a Low-Level Mixed Waste Lab")

M-15-00 Complete the RI/FS (or RFI/CMS) process for all operable units.

M-16-00 Complete the remedial actions for all operable units.

M-17-00A Complete liquid effluent treatment facility/upgrades for all Phase I Streams.

M-17-00B Complete implementation of "best available technology/all known, available, and reasonable methods of prevention, control, and treatment (BAT/AKART) for All Phase II Liquid Effluent Streams at the Hanford Site.

M-18-00 Complete WRAP Module I construction and initiate operations.
Due Date

$6 / 30 / 1994$

$6 / 30 / 1992$

(Completed)

$12 / 31 / 1999$

$10 / 31 / 1995$

09/30/2005

$9 / 30 / 2018$

$6 / 30 / 1995$

$10 / 31 / 1997$

$3 / 31 / 1997$ 
M-19-00 Complete WRAP Module if construction and

$9 / 30 / 1999$

initiate operations.

M-20-00 Submit Part B Permit applications or closure plans for all RCRA TSD units.

$5 / 31 / 1996$

M-21-00 Submit RCRA interim status compliance

$4 / 30 / 1996$ assessments for all TSD Units.

(Completed)

M-22-00 Establish enforceable compliance action schedules.

$12 / 31 / 1989$

(Completed)

M-23-00 Complete interim status corrective

9/30/1991 actions.

(Completed)

M-24-00 Install RCRA groundwater monitoring wells at the rate of 29-CY 1989 , 30-CY 1990, and up to 50 each year thereafter as specified by agreed interim milestones until all land disposal units and single-shell tanks are determined to have RCRA compliant monitoring systems.

M-25-00 Provide annual reports of studies/efforts that are in progress to identify alternatives to land disposal of radioactive mixed waste.

Annually beginning CY 1989

$3 / 31 / 1991$

(Completed)

$10 / 31 / 1990$

M-26-00 Submit Hanford Site land disposal restrictions (Completed)

M-27-00 Submit all aggregate area management study

9/30/1992 reports for the 200 Areas to EPA (Completed) and Ecology as secondary documents.

M-28-00 Submit all soils and groundwater background 4/30/1992 determination documents to EPA and Ecology. (Completed)

M-29-00 Develop and submit documentation to EPA 3/31/1992 and Ecology describing the Hanford Site risk assessment methodology. 
M-30-00 Complete integrated general investigations

9/30/1993

and studies for 100 Area.

(Completed)

M-32-00 Complete identified dangerous waste tank

$9 / 30 / 1999$ corrective actions.

M-33-00 Submit a DOE-signed change package for

$6 / 30 / 1995$ acquisition of new facilities, modification of existing facilities, or modification of planned facilities for storage, processing and/or disposal of solid waste and materials based on the results of the "sitewide systems analysis."

M-34-00 Complete actions specified by agreed interim

$9 / 30 / 2018$ milestones related to remediation of the $\mathrm{K}$-East Basins.

M-35-00 Complete data management enhancements as $9 / 30 / 2018$ negotiated and approved in M-35-00 interim milestones.

M-40-00 Mitigate/resolve tank safety issues for high priority watch list tanks.

$9 / 30 / 2001$

M-41-00 Complete single-shell tank interim

$9 / 30 / 2000$ stabilization.

M-42-00 Provide additional double-shell tank

$12 / 31 / 1998$ capacity.

M-43-00 Tank farm upgrades.

$6 / 30 / 2005$

M-44-00 Issue tank characterization reports

$9 / 30 / 1999$ based on process knowledge, prior characterization data, and validated empirical data acquired after May 1989 for 177 Hanford Site high-activity waste tanks.

M-45-00 Complete closure of all single-shell tank

$9 / 30 / 2024$ farms. 


\section{DOE/RL-94-37}

M-46-00 Double-shell tank space evaluation.

Annually

from

9/30/1994

M-50-00 Complete pretreatment processing of Hanford

$12 / 31 / 2028$ Site tank waste.

M-51-00 Complete vitrification of Hanford Site high-

$12 / 31 / 2028$ level tank waste.

M-60-00 Complete vitrification of Hanford Site lowlevel tank waste.

$12 / 31 / 2028$

M-70-00 Operate the ERDF (available to receive remediation waste) on September 1996.

$9 / 30 / 1996$

Milestones numbers not listed (for example, M-01-00 through M-10-00) have either been deleted in the last Tri-Party Agreement negotiations or have obtained a new milestone number. 
DOE/RL-94-37

\section{Distribution}

Number of Copies

\section{ONSITE}

1

1

4
U.S. Department of Energy.

Richland Operations Office

Public Reading Room A1-65

Pacific Northwest Laboratory

Technical Files

K1-11

Westinghouse Hanford Company

Central Files (1)

L8-04

Document Clearance

Administration (3)

A3-36 
DOE/RL_94-37

This page intentionally left blank. 

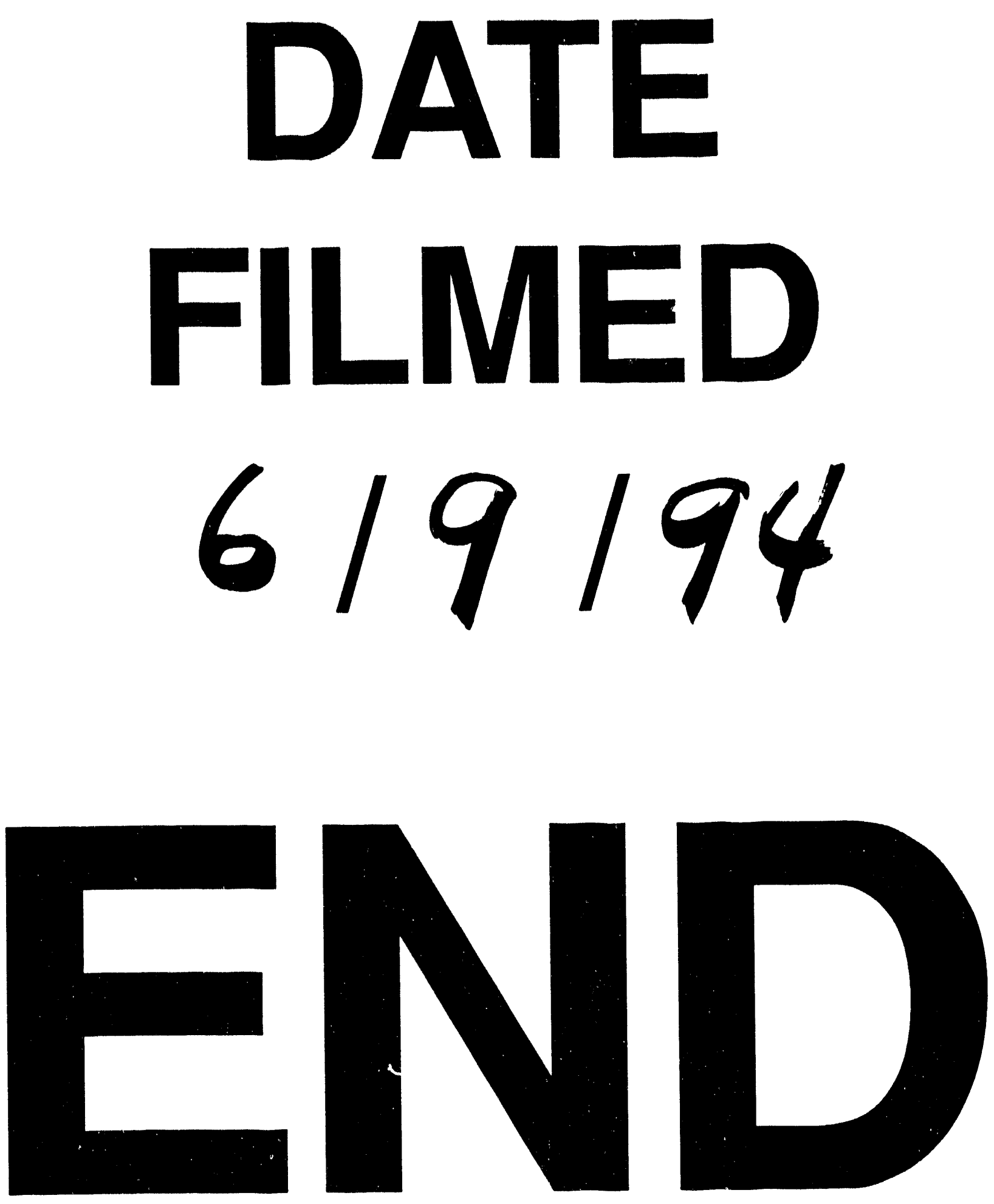